\title{
If Not Now, When? Reasserting Beijing for a Progressive Women's Rights Agenda in 2015 and Beyond'
}

\author{
Abigail Hunt
}

\begin{abstract}
Women's rights organisations have been central to progress on women's rights and gender equality since the adoption of the Beijing Declaration and Platform for Action (BPfA). Drawing on interviews and a survey carried out in January 2015 with 13 Womankind Worldwide's partner organisations, the myriad ways in which women's movement actors draw strategically on the BPfA as appropriate to their context are explored, along with universally-shared implementation challenges.
\end{abstract}

Since 1995 further international frameworks making provisions on women's rights and gender equality have been adopted, including the Millennium Development Goals (MDGs) and United Nations Security Resolution (UNSCR) 1325. The geopolitical context and international development landscape have also shifted significantly. Yet, women's rights organisations consistently hold up the Beijing commitments as the global benchmark of women's rights and gender equality. Therefore, a widespread reassertion of the Beijing Declaration and Platform for Action (BPfA) is crucial in 2015, to re-establish a progressive and transformative women's rights agenda in coming years.

\section{Introduction}

Women's rights organisations continue to hold up the commitments made at the Fourth World Conference on Women in Beijing in 1995 as the eminent global benchmark of women's rights and gender justice. The agreement of the BPfA was a watershed moment, with key actors from the women's rights movement, governments and international institutions, among others, collaborating to produce a visionary and political agenda for global action on gender equality and women's rights. Since then, women's rights organisations have been at the forefront of progress, employing innovative approaches across local, national and international fora to ensure headway is made on the commitments secured in Beijing.

A number of further policy commitments relating to women's rights and gender equality have been agreed since the adoption of the BPfA in 1995, notably MDG 3 and UNSGR 1325, along with subsequent resolutions focusing on the Women, Peace and Security agenda. At the same time, there have been significant shifts in the global geopolitical context, characterised by increased conflict, economic and social insecurity, backlash against gains towards gender justice, and a rapidly changing landscape for international development cooperation.

The year 2015 is an important crossroads for these three intertwined frameworks - with a 20-year stocktake of the BPfA, the agreement of a new post-2015 development framework, and a 15-year high-level review of UNSCR 1325 taking place. Despite these comprehensive policy provisions, implementation has remained inconsistent and incomplete overall and has been accompanied by a discursive and practical shift away from the ambitious, transformative rights-based agenda established in Beijing. The need for a newly invigorated, political focus is urgent to challenge and overcome the entrenched power structures underpinning persistent gender inequality and the ongoing denial of women's rights.

Located within this context, this article explores how the BPfA resonates today. It draws on a written survey and semi-structured interviews carried out in January 2015 with 13 of Womankind Worldwide's partners, women's rights organisations from across Asia, Africa and Latin America. The myriad ways in 
which women's rights organisations have worked to ensure that the 'Beijing blueprint' for women's rights is incorporated into national policies and legislation to achieve contextually-specific gains are considered, along with certain universally-shared challenges in implementation. It is shown that women's movement actors have made strategic decisions to draw on the BPfA, MDG 3 and Women, Peace and Security commitments as appropriate to their context - often in the face of significant backlash. In conclusion, it is argued that a new, truly transformative departure in which structural change is prioritised is an essential prerequisite to the achievement of women's rights. Therefore, a widespread reassertion of the BPfA is crucial in 2015, in order to re-establish a strong tone for a progressive and transformative women's rights and gender justice agenda in the years ahead.

\section{Women's rights organisations at the forefront of progress}

Women's rights organisations can be defined as 'women-led organisations working to advance gender equality and women's rights', and comprise a huge spectrum and diversity. Many are self-led, for example comprising and working with certain groups such as rural women, migrants, domestic workers, dalit women or women living with disabilities or HIV (Esplen 2013). They often employ a feminist analysis to challenge 'traditional' gender roles, unequal gender power relations and structural inequalities, and support women to address their own practical needs and strategic interests.

While there is a vast literature on the form of women's rights organisations and the work they carry out, the 'value-added' of organisations led and managed by women is comprehensively accounted for by O'Connell (2012), who highlights their extensive experience and understanding of genderbased discrimination and inequality, their relevance and connectedness to women's lives, and their understanding of the political nature of, and approach to, organising for change as they support women to come together and know their rights. This narrative on the unique and crucial role of women's rights organisations and women's movements is corroborated by a large-scale analysis of violence-against-women policies (Htun and Weldon 2012) which clearly demonstrate that the mobilisation of feminist movements is the principal factor in securing change for women, ahead of other factors such as national wealth or high representation of women in politics.

The importance of national conventions, resolutions and decisions lies in the impetus and legitimacy they give to the struggle of women at the national, local and household levels, as women claim equality and rights in their own lives (Pietilä and Vickers 1996). Women's rights organisations have been active in a myriad of ways to secure contextuallyspecific gains against the 'Beijing blueprint', which often includes supporting self-led, collective action which empowers women to assert their rights and challenge structural inequality at all levels, as interviews with Womankind partner organisations clearly demonstrate. ${ }^{1}$ Recognising that most of the journey towards the realisation of women's rights is travelled after international policies are developed, women's rights organisations have been crucial in setting the tone and agenda nationally and locally for their implementation, and have been effective partners in the innovative and sustainable women's rights-focused programming that has secured change (Cornwall 2014).

Women's rights organisations rarely operate in isolation, and they draw significant strength from globally interconnected women's movements. As one Womankind partner organisation representative explained, the support of larger women's rights organisations to smaller or more informal groups within the women's movement has led to their evolution from unstructured groupings into coherently organised entities capable of effectively influencing the social, economic and political discourse. ${ }^{2}$ As another explained, international and regional women's movement networks have proved crucial in sharing knowledge on international processes and bolstering the strength of national women's rights organisations. Information about international commitments does not always flow through governments to local women's rights organisations, meaning that movement networks are a crucial conduit of knowledge and information. ${ }^{3}$

Womankind's partners also report a number of universally-shared challenges in the implementation of international and national policy frameworks. Although commitment to and actual progress varies significantly across country contexts, recurring trends can be identified globally: domestication or localisation of international agreements such as the BPfA remains incomplete; the resources (both political and financial) necessary to implement policies are insufficient or absent, as is capacity and knowledge on women's rights - even within state women's ministries and machineries; and there continues to be a lack of long-term monitoring or follow-up on policy commitments, often due to the absence of built-in accountability systems within policy frameworks. 
Women's rights organisations have tried to address this gap by monitoring compliance of international obligations by governments, actively participating in the preparation of both state party and shadow civil society periodic reports on progress, even where civil society monitoring reports are not officially mandated or recognised by governments. Similarly, women's rights organisations have established accountability mechanisms and fora at the national and local level; for example, in Peru the Federación de Mujeres de Ica has established public hearings with women decision-makers during which these leaders report on progress on implementation of public policies in favour of women.

Other frequently cited challenges to the implementation of the BPfA, and which women's rights organisations are consistently working to counter, include the persistence of negative social norms, attitudes and discrimination against women which continue to be reinforced by the media, male traditional and political leaders; the influence of religious institutions and leaders over the state and public; and the persistence of practices which deny women's rights in the name of 'tradition' or culture'. However, Womankind partner organisations unanimously confirmed that the most significant challenge facing women's rights organisations globally is increasingly difficult access to financial resources. Changing aid modalities, an increase in actors such as mainstream non-governmental organisations (NGOs) 'doing gender', and an increased desire for 'quick wins' by donors all contribute to the difficulties faced by women's rights organisations in accessing the core, flexible and sustainable funding needed to enable them to carry out the long-term work that social transformation requires, an issue discussed further below.

\section{Twenty years on: the relevance of the BPfA}

Following the adoption of the BPfA in 1995, a number of international policy frameworks relating to women's rights and gender equality have been agreed. The MDGs, including MDG 3 which aimed to 'promote gender equality and empower women', were adopted in September 2000. UNSCR 1325, which has been accompanied by six subsequent resolutions - together comprising what has become known as the international Women, Peace and Security framework ${ }^{4}$ - was adopted in October 2000. Neither of these two subsequent frameworks was welcomed by women's rights organisations and the wider women's movement as the BPfA had been. Many women's rights organisations interviewed by Womankind felt the MDGs were unnecessary, and diverted states and other key stakeholders from the progressive commitments to which they had signed up in Beijing. Demonstrating the feeling of many other women's rights activists, a representative of the Womankind partner organisation, Saathi, noted how the women's movement in Nepal relabelled the MDGs among themselves as the 'Most Distracting Gimmick' upon their launch, as they turned attention away from the more comprehensive and transformative agenda established in Beijing.

The rejection of the MDGs by some within the women's movement occurred also as a result of the top-down and non-participatory manner in which the MDGs were conceived and developed, which stood in stark contrast to the mass mobilisation and dialogue between diverse stakeholders which had taken place in Beijing some five years earlier. Many women's movement actors attending the Fourth World Conference in 1995 felt that the process leading to the establishment of the BPfA had been highly collaborative and inclusive of them and their demands. On the other hand, the draft MDGs have become notorious for having been written - and at times even improvised - by a small team 'in a basement office at the UN in New York' and then launched with minimal consultation with wider stakeholders (Tran 2012). As Saathi's representative confirmed, 'Women activists didn't want anything to do with the MDGs... it was a top-down approach. Women's rights organisations and civil society weren't engaged in the process. It was difficult to build ownership of the MDGs'.

Some of the representatives of women's rights organisations interviewed felt that the MDGs were a deliberate, patriarchal attempt to roll back on the commitments secured in Beijing and an attack on the progress secured in the immediate years after the establishment of the BPfA. Many interviewees agreed that in comparison to the BPfA, which continues to be seen as a comprehensive and visionary framework for women's rights, the MDGs, including MDG 3, were extremely narrow in scope. Most crucially, the MDGs narrowed and depoliticised the women's rights and gender justice agenda, through their failure to recognise the underlying structural conditions and power relations which create and maintain gender inequality and discrimination (Hunt and O'Connell 2015). As Emily Sikazwe explained:

By diluting the BPfA and coming up with MDGs many nations of the world had turned a blind eye to the fact that we had already done very 
good work to develop and implement the BPfA. We didn't need the MDGs. We have made some progress, but we can make far more by reclaiming the BPfA. ${ }^{6}$

One aspect emerging clearly from Womankind's research is that while most women's rights organisations recognise the BPfA as the ideal standard or 'benchmark' women's rights framework, in reality its lack of resonance - notably with their country's government - means that some have made strategic decisions on which international agreement to invoke for best resonance and impact in-country, employing the Convention on the Elimination of All Forms of Discrimination against Women (CEDAW) and regional frameworks such as the Maputo Protocol, ${ }^{7}$ or the international Women, Peace and Security framework where most useful.

For example, the very specific provisions of some frameworks, for example UNSCR 1325 and subsequent resolutions, have been particularly useful to women's rights organisations in conflict-affected countries when advocating for gender-sensitive conflict resolution and peace-building processes. One Womankind partner organisation said: '[We] work on the instrument that is most supported by the government and international NGOs within the country - and that's 1325. They fund more work on 1325 in comparison to other instruments'.

Others also see the Women, Peace and Security framework as more relevant and easily applied in their operational context than the BPfA or the MDGs, whose timeline for achievement has not been applied consistently across all countries. As one partner organisation in Afghanistan elaborated: 'UNSCR 1325 is more useful. It is more simple than others, and has been followed up by the government, which has at least given some importance to preparing a National Action Plan and timeframe for its implementation'. ${ }^{9}$

In both of these cases, women's rights organisations have made strategic decisions based on practical considerations around the most valuable international framework to invoke to achieve their aims. Crucially, they have eschewed the BPfA not because of a lack of belief in its progressive and transformative potential, but because of their judgement of its resonance and leverage with the actors they aim to access and influence. As one partner explained, 'Beijing laid the main groundwork, but the [Women, Peace and Security] framework complements it. Our country was affected by conflict from 1996 to 2006, and only after 2004 was the relevance of 1325 realised, and a few of us started using it in advocacy'. ${ }^{10}$

It is notable that some of the women's rights organisations interviewed mentioned having invoked the Women, Peace and Security framework in their work more frequently than the MDGs. A primary factor for this is the legitimacy afforded to the former as its adoption was the result of intense, sustained lobbying by the women's movement itself, much like the BPfA. However, its particular relevance to conflict-affected countries renders the UNSCR 1325 of more strategic value to some women's rights organisations than others.

While the new, universal post-2015 agenda should ensure coherence with the strongest elements of both the MDGs and the Women, Peace and Security framework, it must also significantly advance international commitments to a universallyapplicable vision for women's rights and gender justice. Still widely accepted as a relevant and globally-applicable benchmark for women's rights, the BPfA offers this vision, accompanied by practical steps towards its achievement.

\section{5 and beyond: a progressive women's rights agenda?}

In 2015, a 20-year progress review of the BPfA and a 15-year high-level review of UNSCR 1325 are taking place, offering critical opportunities for women's rights organisations, governments and other stakeholders to take stock and identify gaps in progress against these agendas to inform future implementation. Perhaps most crucially, negotiations will culminate in the adoption of a post-2015 development framework, the successor to the MDGs.

Efforts are being made by the UN entities leading the post-2015 negotiations to ensure the process is considerably more participatory than the development of the MDGs, which has included widespread consultations with multiple stakeholders - including civil society. As the post-2015 development process has also included women's rights organisations and movement actors, including Womankind and partner organisations, the final framework adoption and implementation provide a huge opportunity to galvanise support for women's rights and bring on board new actors to collaborate on a gender justice agenda. Getting the tone and focus right in the post-2015 framework is also crucial in practical terms as its goals, targets and indicators will define where significant political will and 
resources should be channelled until 2030 (Smee and Woodroffe 2013).

However, while the opportunities to secure new and tangible commitments presented throughout 2015 are unprecedented, never has the risk of regression on the practical and strategic gains achieved by women worldwide in the past decades been higher. Recent development trends have rarely demonstrated commitment to the structural change required to ensure long-term, sustainable change for gender equality, nor have they prioritised an approach framed around the meaningful achievement of gender justice and women's rights. Instead, benign interpretations of 'women's empowerment' and instrumentalist discourse and approaches have proliferated (see Cornwall and Rivas 2015; Grosser and van der Gaag 2013).

The realisation of de facto gender justice is also in peril as a result of significant shifts in the geopolitical situation, characterised by increased militarism and conflict, economic crisis, social insecurity and mounting religious fundamentalisms (see AWID 2015). Ongoing attacks on women's rights are taking place, both in terms of the use of rights language and the rollback of legal and policy provisions at national level in numerous contexts, accompanied by attempts by conservative governments and social actors to limit women's individual or collective empowerment as envisaged by feminist scholars (see Kabeer 1994; Rowlands 1997). This is perhaps most clearly seen during the annual United Nations Commission on the Status of Women (CSW), where governments increasingly struggle to reach consensus on the adoption of Agreed Conclusions, with well-organised and well-funded conservative governments acting together to repeal women's rights provisions, often contesting previously agreed language.

The new framework must go further than 'building on the MDGs', yet recent CSW and post-2015 negotiations have indicated that inter-governmental agreement of a 'new', progressive framework for women's rights is improbable. Indeed, many - including more progressive states in terms of women's rights - are convinced that aspirational commitments such as those agreed in Beijing could never be agreed today, and that opening up the BPfA text for review would inevitably lead to a reversal of its commitments (Goetz and Sandler 2015). As a precedent in international, UN-focused fora is established for drawing on previously agreed language, texts and commitments, as seen annually at CSW, a reassertion of previously agreed commitments to the BPfA offers a more realistic opportunity to re-establish a progressive agenda for women's rights and gender justice in 2015 and beyond than attempting to negotiate a brand new agreement.

This commitment must be made across high-level political fora, and also bring in a range of 'new' and 'old' actors (Miller, Arutyunova and Clark 2014). Moving away once and for all from the established binary within dominant international development approaches in which countries are split into 'global North donors' and 'global South recipients' is crucial if the post-2015 framework is to be responsive to the changing global development context. As the crucial change agents for mobilising for social change towards gender equality (Htun and Weldon 2012), women's rights organisations should logically be central to all new approaches to supporting women's rights and gender justice. Yet the approaches of new actors often limit women's rights organisations' ability to define locally-relevant priorities, with women's rights organisations increasingly treated as market-based service suppliers instead of being seen as the innovators and vital change agents they are (Mukhopadhyay and Eyben 2011).

\section{One Womankind partner, Women for Change} in Zambia, sees women's rights organisations as increasingly becoming 'contracted labourers', or more derisively, 'foot soldiers on the ground', to international donors with a predefined agenda, including international NGOs who have relatively recently started 'doing gender', with women's rights organisations being forced to submit bids for predefined projects not intrinsically aligned to their own organisation's mission in order to secure their existence. This increasingly common trend has numerous negative implications, most notably that while women's rights organisations' capacity is diverted into projects only nominally drawing on their contextually-relevant knowledge, skills and expertise, their ability to develop and implement the kind of transformative and feminist initiatives in which they specialise - and which are essential for the sustainable realisation of gender justice and women's rights - becomes severely limited. As Women for Change's representative explained: 'Women's rights organisations are being forced to take on other issues, other than what their visions and missions say to keep their organisations afloat. Calls for proposals come and it is not directly about what we do but because we need to keep afloat we are forced to compete'. ${ }^{11}$ 
The recent trend towards a dominant instrumentalist rhetoric around women's empowerment within mainstream development has already narrowed the discursive space and practical opportunities for the implementation of a truly transformative new agenda. A post-2015 framework which fails to focus on and give mainstream legitimacy to tackling multiple sites of gendered power will conceivably further constrain the political, feminist approaches often prioritised by women's rights organisations and women's movements.

In this context, the women's rights and gender justice agenda upon which much progress in tackling deeply-rooted gender inequality has been based risks becoming increasingly seen as the 'radical' wing of a largely depoliticised mainstream development 'gender agenda'. As a result, two possibilities emerge: first, that politicised, gender justicefocused women's rights organisations and women's movement actors become increasingly marginalised from the mainstream, further reducing their ability to access the resources and support of traditional and new donors; or second, in line with movement actor strategies conceptualised by Benford and Snow (2000) and Tarrow (1998), women's rights organisations are increasingly forced to depoliticise and reframe their claims to resonate with the dominant discourse and maximise their political opportunities, as well as to increase access to the resources needed for their survival.

Given the evidence of the crucial role of feminist and gender justice-focused women's rights organisations and women's movements in achieving multi-level change for women's rights, the realisation of either circumstance poses in turn a significant threat to the achievement of any gender-focused post-2015 objective agreed, including the innocuously framed 'achieve gender

\section{Notes}

* The author wishes to thank again the 13 women's rights organisations who participated in the interviews which informed this article. Thanks also to Helen O'Connell, who was joint lead of Womankind's 'At the Crossroads' research project, and who provided input to this article.

1 For further information about how women's rights organisations have worked to secure gains against the BPfA and other international commitments see Hunt and O'Connell (2015).

2 Written survey response received from Christine Ochieng, Federation of Women Lawyers, Kenya, 14 January 2015. equality and empower women and girls' or the 'leave no one behind' principle emerging from post-2015 negotiations to date (United Nations 2013, 2014).

\section{Conclusion}

Current attention on the future international development framework offers a huge opportunity to rectify the omissions of the MDGs and to recentre and revitalise the increasingly instrumental discourse around women's empowerment, moving instead towards a new, truly transformative departure which prioritises structural change as an essential prerequisite for the achievement of women's rights. Moreover, a widespread re-establishment of commitments to the BPfA by all governments, 'new' development actors and international institutions can be seen as a vital precursor to the achievement of the widespread, sustainable social change needed for substantive gender equality and respect for women's human rights.

This new approach would see synergies built between these 'new' and 'old' actors, with their close cooperation built on a shared vision for gender equality, with recognition of and support to women's rights organisations at its core. The need for a newly invigorated, political focus is urgent, in which the entrenched power structures underpinning persistent gender inequality and the ongoing denial of women's rights are challenged and overcome. This would see a critical mass of united actors acting to secure an overhaul of current gendered power relations, from household to community, local, national and international levels. Anything less will open the way for further, and potentially irretrievable, subversion of the feminist, transformative agenda upon which progress on women's rights and gender justice to date has been built, and to which women's rights organisations and movements have historically been central.

3 Interview with María Ysabel Cedano, Estudio para la Defensa de los Derechos de la Mujer, Peru, 5 January 2015.

4 UNSCR 1820 (2009); 1888 (2009); 1889 (2010); 1960 (2011); 2106 (2013); and 2122 (2013).

For more information see www.un.org/en/ peacekeeping/issues/women/wps.shtml.

5 Interview with Bandana Rana, Saathi, Nepal, 15 January 2015.

6 Interview with Emily Sikazwe, Trustee, Women for Change, Zambia, 8 January 2015.

7 Full title: Protocol to the African Charter on Human and Peoples' Rights on the Rights of Women in Africa. 
8 Interview with Estella Nelson, Liberia Women's Media Action Committee, Liberia, 8 January 2015.

9 Interview with Maryam Rahmani, Afghan Women's Resource Centre, Afghanistan, 15 January 2015.

\section{References}

AWID (Association for Women's Rights in Development) (2015) AWID Presents some Highs and Lows for Women's Rights and Gender Fustice in 2014, www.awid.org/News-Analysis/Friday-Files/ AWID-Presents-Some-Highs-and-Lows-forWomen-s-Rights-and-Gender-Justice-in-2014 (accessed 28 February 2015)

Benford, R. and Snow, D. (2000) 'Framing Processes and Social Movements: An Overview and Assessment', Annual Review of Sociology 26: 611-39

Cornwall, A. (2014) Women's Empowerment: What Works and Why? WIDER Working Paper 2014/104, Helsinki: World Institute for Development and Economics Research

Cornwall, A. and Rivas, A-M. (2015) 'From "Gender Equality" and "Women's Empowerment" to Global Justice: Reclaiming a Transformative Agenda for Gender and Development', Third World Quarterly 36.2: 396-415

Esplen, E. (2013) Leaders for Change: Why Support Women's Rights Organisations?, Womankind, www. womankind.org.uk/wp-content/uploads/ downloads/2013/03/LeadersForChange-FINAL. pdf (accessed 28 February 2015)

Goetz, A.M. and Sandler, J. (2015) Women's Rights have no Country, Open Democracy, 5 January, www.opendemocracy.net/5050/anne-mariegoetz-joanne-sandler/women $\% 27$ s-rights-haveno-country (accessed 28 February 2015)

Grosser, K. and van der Gaag, N. (2013) 'Can Girls Save the World?', in T. Wallace, G. Porter and M. Ralph-Bowman (eds), Aid, NGOs and the Realities of Women's Lives: A Perfect Storm, Rugby: Practical Action Publishing

Htun, M. and Weldon, S.L. (2012) 'The Civic Origins of Progressive Policy Change: Combating Violence against Women in Global Perspective 1975-2005', American Political Science Revierw 106: 3

Hunt, A. and O'Connell, H. (2015) At the Crossroads: Women's Rights after 2015, Womankind Worldwide, www.womankind.org.uk/download/19804/ (accessed 28 February 2015)

Kabeer, N. (1994) Reversed Realities: Gender Hierarchies in Development Thought, London: Verso
10 Interview with Bandana Rana, Saathi, Nepal, 15 January 2015.

11 Interview with Emily Sikazwe, Trustee, Women for Change, Zambia, 8 January 2015.

Miller, J, Arutyunova, A. and Clark, C. (2014) New Actors, New Money, New Conversations: A Mapping of Recent Initiatives for Women and Girls, Association for Women's Rights in Development, www.awid. org/Library/New-Money-New-Actors-NewConversations (accessed 28 February 2015)

Mukhopadhyay, M. and Eyben, R. (2011) Rights and Resources: The Effects of External Financing on Organising for Women's Rights, Brighton and Amsterdam: Pathways of Women's Empowerment and Royal Tropical Institute

O'Connell, H. (2012) What Added-value do Organisations that are Led By and Managed By Women and Girls Bring to Work Addressing the Rights, Needs and Priorities of Women and Girls?, Comic Relief Review Paper, London: Comic Relief

Pietilä, H. and Vickers, J. (1996) Making Women Matter: The Role of the United Nations, 3rd edn, London: Zed Books

Rowlands, J. (1997) Questioning Empowerment: Working with Women in Honduras, Oxford: Oxfam

Smee, S. and Woodroffe, J. (2013) Achieving Gender Equality and Women's Empowerment in the Post2015 Framework, Gender and Development Network, https://gad-network.squarespace. $\mathrm{com} / \mathrm{s} /$ Achieving-gender-equality-and-womensempowerment-in-the-post-2015-framework-vlcb. pdf (accessed 28 February 2015)

Tarrow, S. (1998) The Power in Movement: Social Movements and Contentious Politics, Cambridge: Cambridge University Press

Tran, M. (2012) 'Mark Malloch-Brown: Developing the MDGs was a bit like Nuclear Fusion', The Guardian, www.theguardian.com/globaldevelopment/2012/nov/16/mark-mallochbrown-mdgs-nuclear (accessed 5 May 2015)

United Nations (2014) Report of the Open Working Group of the General Assembly on Sustainable Development Goals, A/68/970, http://undocs. org/A/68/970 (accessed 28 February 2015)

United Nations (2013) A New Global Partnership: Eradicate Poverty and Transform Economies through Sustainable Development: The Report of the High-Level Panel of Eminent Persons on the Post-2015 Development Agenda, New York NY: United Nations Publishing 